\title{
TAKING BACK CONTROL OF OUR STORY SPACE: A FOREWORD
}

\author{
FRANK ESPINOSA
}

"HE WhO CONTROLS THE SPICE, controls the Universe" - so says Baron Harkonnen in Frank Herbert's revolutionary science fiction classic Dune. These words set the stage for the epic struggles and the motivations that will shift the galactic power and bring the Fremen to their destiny.

These are our lives, and these our stories. Let us shape them both with our wills. Let us write them all down, explore our culture with drawings, and fill these modern caves with our lovely handprints. We will play these stories in our music and sing it with our songs. This is our spice.

To take back control of our own stories is to destroy all forms of helotry. From the smallest fairy tales, told to our children, to the largest of our epics that sing to the future.

And this is where Graphic Borders comes in. Within these pages you will find the tales of one after another of Latino creators. You will learn who they are, and you will investigate what is behind the strokes of brush and flourishes of pen. With every page turned, the bounteous symbols of our great Latino visual literature become known to you.

So delicate is this new Latino symbolization that much of it is unknown, even, dare I say, to some of the very artists who write, draw, and create our new stories. As artists, we work so hard and fast that it is impossible to see one's work in all its facets at once. Aldama and González's book acts like a mirror. It does the job of reflecting our work. It gives us a new dimension to work toward.

As we all know, magic mirrors are important in many stories, from Narcissus's, to Snow White's, to Alice in Wonderland's. Sometimes those mirrors show the future; other times they become in themselves a doorway to a different world. This is what Aldama and González have so masterly crafteda book that lets us see ourselves. This is a book that peels back the layers so we can understand, experience illumination-so that we can have reflection. 
With Graphic Borders you walk into new fissures-new territories of meaning. Graphic Borders helps us to experience Latino comic symbology in an entirely new way. As a people constantly faced with borders, Latinos have learned to sleuth out gaps-dangerous passages that can and do lead to the newly imagined. Aldama and González invite you into the gaps, those liminal spaces whereby you will travel straight into a Latino visual and mental superbarrio. Aldama and González are the Trainmen in what can be seen as the Latino iteration of The Matrix's Mobil Ave-a smuggling portal for exile programs to enter the main source. They are the guides who transport us to and through a new superbarrio that is being created with words and brushstrokes.

We all work from our own personal understanding of things. Each of us brings together, during the act of creation, colors, sights, sounds, tastes, language, and experiences from many different influences in our lives. We become a channel to our past and future. As creators, we then mix up this creative soup with our brushes, sharpen our pencils with it, or remix our paints with this Latino combination of emotion, memory, and familiarity of culture.

This book is a reflection of exceptionally brave Latino artists, writers, and storytellers who are clearing a rich and complexly layered space within a world that often excludes us - that even desperately seeks to pave over us. Sadly, many artists who work extremely hard are sometimes forgotten. We all exist in a persnickety modern world. The flavor of the month changes as easily as Flash and Superman change their costumes. This book, with its resplendent thought pieces and interview, make sure we are not forgotten. It's the respirator that keeps me and my comic book creations pumping with life. In this twenty-first-century Archimedes mirror, we Latino creators are reflected back much stronger than ever. What a blessing that is.

Whoever controls the stories controls the borderland space of el Super Barrio. Enjoy, reflect, create . . cuidate. 
GRAPHIC BORDERS 
THIS PAGE INTENTIONALLY LEFT BLANK 